\title{
Investigation of the Relationship between Emotion Socialization Behaviors of Mothers and Temperament of Children ${ }^{1}$
}

\author{
Sema Öngören, Nevșehir Hacı Bektaş Veli University, Turkey, ongorensema@gmail.com, ORCID: 0000- \\ 0002-6034-1400
}

Gülhan Köçer, Süleyman Demirel University, Turkey, gulhankocer@sdu.edu.tr, ORCID: 0000-0002-35573285

Abstract. This study was conducted to determine the relationship between emotion socialization behaviors of mothers and temperament of children. The relational screening method was used. The research sample consisted of 168 children aged 48-72 months and their mothers. In order to collect data, a "Personal Information Form" created by the researcher regarding parents and children, the "Coping with Children's Negative Emotions Scale" to determine the emotion socialization behaviors of mothers, and a "Short Temperament Scale for Children" to determine temperament features of children were used. The relationship between emotion socialization behavior of mothers and the temperament of their children was investigated using the Pearson correlation coefficient and multiple and simple linear regression analyses. At the end of the study, it is concluded that there is a relationship between emotion socialization behaviors of mothers and temperament of children. It has been determined that encouraging and condescending reactions to the feeling of emotion among mothers' socialization behaviors are predictors for temperament of children.

Keywords: Negative emotion, reaction, temperament, rhythmical

Received: 09.03.2020 Accepted: 06.08.2020

Published: 01.12.2021

\section{INTRODUCTION}

Emotions play a critical role in the human struggle for survival by expressing what is essential, and at the same time, they motivate us to manage our relationships with people and objects. Emotions are contextual and occur as a result of a relationship with something or someone. In this way, emotions are influenced by the movements of others, events occurring in the world, and events in the inner world of the person (Root \& Denham, 2010). Emotions are tools for evaluating our experiences and preparing us to act. Emotions play an important role in many areas of child and adolescent development, including social functioning, academic performance, and developmental psychopathology (Cole, Martin \& Dennis, 2004; Root \& Denham, 2010).

Emotions are the first language in which parents and children communicate with each other (Santrock, 2011). Children learn the emotions and how to regulate them in the family. Families differ from each other regarding which emotions are expressed and which cannot be revealed, and the way in which they express emotion varies from family to family. Parents' feelings of emotion become models for children to experience emotions and to deal with emotions. In this context, it can be said that the role of the family is significant, especially in early development periods (Southam-Gerow, 2014). Although emotions are somewhat biological, socialization takes place primarily through interactions within the family in the first years of life, and the meaning of emotions and the proper socialization of emotional expression can affect the process of emotion socialization of both parents and children (Eisenberg, Cumberland \& Spinrad, 1998; Southam-Gerow, 2014). In recent years, there has been a renewed interest in emotions in almost all areas of psychology, and studies on how to use the emotion socialization label, such as understanding, experiencing, explaining and regulating the emotions of children in socialization, have increased (Eisenberg, Cumberland \& Spinrad, 1998). Emotion socialization is a process during which important people for children, especially their parents,

\footnotetext{
${ }^{1}$ This study was presented at the 5th International Early Childhood Education Congress
} 
are instructive about emotion and its regulation. Besides, emotion socialization involves parents' behaviors that reflect their beliefs, goals, and values about their children's experiences, explanations, and emotions (Eisenberg, Cumberland \& Spinrad, 1998; Southam-Gerow, 2014).

There are several ways in which emotion socialization occurs in the family, such as parent-child bonding, which is the direct teaching of the parent's emotional regulation, and talking about emotion between the parent and child (Southam-Gerow, 2014). The roots of emotions extend to the process of attachment, and the mutual exchange of emotions forms the main component of the attachment process (Ruppert, 2014). Clearly, the relationship between the mother and the baby in the very first years after birth is the basis for the development of lifelong emotional capacity as well as the secure attachment of the baby (Soysal \& İseri, 2010). Parents socialize and evaluate children's emotional behavior for the direct management of the child's emotions. Supporting behaviors allow emotion regulation because such support helps to reduce negative emotions. Emotion conversations between parents and children are an essential way for parents to socialize their emotions. These conversations can be during or after events involving sensuality. Understanding that emotions are a normal part of humans is also helpful in regulating emotions (Eisenberg, Cumberland \& Spinrad, 1998; Southam-Gerow, 2014).

Effective emotion socialization involves developing children's capacity to experience all emotions, understand their own and others' feelings, and effectively regulate their emotions. Parents can contribute to the emotional development of their children through directly creating an emotional environment at home or indirectly giving reactions to the emotions of their children (Eisenberg, Spinrad \& Cumberland 1998; Denham, 1998; Hastings \& De, 2008). Secer (2017) states that emotion regulation of children varies according to social competence levels, and that mothers' emotional socialization behaviors are a significant predictor of emotion regulation; Özen-Uyar, Yılmaz Genç \& Aktaş Arnas (2018) state that mothers' emotional socialization behaviours are a significant predictor of emotion regulation for preschool children. Hastings and De (2008) state that the reactions of the father to the anger of children and the mother's responses to the sadness and fears of children are closely related to the social competence, introvert and extrovert problems of children.

The family has a significant impact on the temperament and habit styles of the child as well as on his/her emotional development. In general, the emotional state of the family affects the emotional development of the child, as well as influencing the overlap level between the temperament and habits of the child in his/her life and theirs (Southam-Gerow, 2014). Reactiveness in the early period, and the constant individual differences in self-regulation are defined as temperament (Berk, 2013). Behavioral styles, emotions, characteristic direction, and individual differences in response also reflect temperament. In other words, temperament is the basic orientation that forms the basis of innate personality and can be observed throughout the development of individuals (Bee \& Boyd, 2009; Santrock, 2011; Trawick-Smith, 2014).

Infants are often born with a variety of temperament types that will affect their social relationships and emotional health for years to come (Trawick-Smith, 2014). Thomas and Chess (1977) group the temperament of babies in three categories: easy, difficult and slow to warm up. The easy child adapts to changes easily and shows regular eating, sleeping and waking patterns. Infants with an easy temperament are friendly, cheerful, friendly towards people they do not know, and can be comfortably consoled. The difficult child behaves in an irritable and disordered manner. Infants with a difficult temperament immediately cry and show less positive emotions. They react negatively to new situations and to the people they do not know. The child who is slow to warm up may seem unresponsive, but in fact, they react later than other children. These children have a more passive resistance. Children with a slow-to-warm-up temperament are cautious against foreigners, and reluctant to leave their parents. They often do not express their positive or negative feelings. In each category, children show their own personality traits in varying proportions.

Today, one of the most effective temperament models is Mary Rothbart's model. The six sub-dimensions of this model represent the three main components included in the definition of temperament: (1) emotion (fearful stress, restless stress, positive affectivity and plausibility), 
(2) attention (attention span \continuity), and (3) action (activity level). According to Rothbart, individuals differ not only in their responsiveness to any dimension, but also in effortful control, which is the self-regulatory dimension of temperament (Rothbart \& Bates, 2007). Differences in control requiring effort are evident in how children focus, how they shift attention, how they control their impulses, and how they deal with negative emotions (Berk, 2013).

Many conditions around the child may increase or decrease the resistance of temperament characteristics (Santrock, 2011). For example, gender may be an important factor shaping the nature of temperament. Boys and girls may adopt different emotion-regulating behaviors depending on their own social environment (Cassano, Perry-Parrish, \& Zeman, 2007). Fathers and mothers may give different reactions to the temperament of the child depending on gender. In a similar way, the reaction to the temperament of the baby may differ depending on the culture (Santrock, 2011). In terms of the relationship with emotion, temperament reflects individual differences, how fast it is shown, how strong it is, how long it lasts, and how long it takes for it to fade (Santrock, 2011), and while children inherit physiology that affects their ability to gain a certain temperament style, they can learn to change their temperament through experience to some extent (Berk, 2013; Santrock, 2011; Trawick-Smith, 2014). The child's relationships and experiences shape, reinforce, stretch or inactivate the innate temperament differences (Bee \& Boyd, 2009). It has been found that children at the age of walking who are criticized by their mothers because of their shy behaviors exhibit shier behaviour compared with children whose personality characteristics are accepted by their mothers in the preschool period (Bee \& Boyd, 2009). Children are born with different behavioral repertoires or patterns to some extent, and these differences not only affect the experiences of a child, but also help shape the pattern of interaction between parents and children (Bee \& Boyd, 2009).

Considering that one of the most important identification models of a child is his mother, and that he/she establishes a long-term relationship with her, it is revealed that the interaction between the mother and the child's reactions towards feeling socialization are shaped according to the child's temperament and that at the same time, this is effective on shaping the child's temperament. When the literature is examined, it is seen that there are many studies on negative emotions and emotion regulation behaviors (Ari \& Yaban, 2016; Blair, Denham, Kochanoff \& Whipple, 2004; Fabes, Hanish, Martin \& Eisenberg, 2002; Guven, 2013; Korkmaz, 2016; Saritas \& Gencoz, 2011; Shewark \& Blandon, 2015; Silk et al., 2011), whereas the number of studies on temperament characteristics and emotion socialization behaviors are limited. For this reason, different research studies related to this topic are needed. Accordingly, the aim of this research is to investigate the relationship between mothers' emotion socialization behaviors and the temperament of children. Within the context of this research, it is thought that the findings will be a guide for deepening the mothers' reactions of socializing emotion and developing the existing programs intended for the parent-child relationship.

\section{METHODS}

\section{Research Design}

This study, which investigates the relationship between the emotion socialization behaviors of mothers and the temperament of children, is designed and conducted as a descriptive research with the relational screening model. The relational screening model is a research model that aims to determine the presence or degree of interaction between two or more variables (Karasar, 2016).

\section{Study Group}

The study group of this research consisted of 250 mothers and their children aged between 4872 months attending ten preschool institutions in Nevşehir city center. Seven of the preschool institutions, which were determined by random cluster sampling, are independent preschools and the other three are connected to primary schools. Following the exclusion of the missing values from the analysis, the number of participants decreased to 168, and all analyses were performed on these corrections. When the demographic features of the children are considered, 
$42.9 \%$ of the children were girls, and $57.1 \%$ of them were boys; $23.8 \%$ of these children were 36-48 months old, $40.5 \%$ of them were $49-60$ months old, and $35.7 \%$ of them were $61-72$ months old. $50.6 \%$ of the children were the first child of the family, while $34.5 \%$ were the second, and $10.7 \%$ were the third. $32.1 \%$ of the mothers who participated in the study were between $20-30$ years old, $31.40 \%$ of them were between $31-40$ years old, and $6 \%$ of them were 41 years old and over. $35.7 \%$ of the mothers were educated at primary or secondary level, $54.8 \%$ had a degree at associate or bachelor's level, and 9.5\% had a degree at postgraduate level.

\section{Data Collection Tools}

A "Personal Information Form," a "Coping with Children's Negative Emotions Scale" and the "Short Temperament Scale for Children" which was created by the researchers, were used as data collection tools.

Personal information form. This consists of questions about the child's gender, age, birth order, mother's age, and educational status.

Short Temperament Scale for Children. This is a six-point Likert type (1- Almost none, 6- Almost always) scale consisting of 30 items developed by Sanson and Oberklaid (1989), and adapted into Turkish by Yagmurlu and Sanson (2009). The scale has four sub-dimensions: reactivity, persistence, friendliness, and rhythmicity. The reactivity dimension measures the readiness of a child to react to a specific stimulus or incident, the persistence dimension measures the concentration of a child on an event, the friendliness dimension measures whether the child has a tendency to approach new people and environments, and the rhythmicity dimension measures the regularity of any function of the child (sleep, hunger, toilet, etc.) over time. Cronbach's alpha internal consistency coefficient for the scale used by Yagmurlu and Altan (2010) in their study was calculated as .79. for the friendliness sub-dimension, .69 for the reactivity sub-dimension, .75 for the persistence sub-dimension, and .63 for the rhythmicity sub-dimension. The Cronbach alpha internal consistency coefficient of the scale used in this study is stated to vary between .55 and .79 .

Coping with Children's Negative Emotions Scale (CCNES). In order to measure the emotion socialization behavior of mothers, the "Coping with Children's Negative Emotions Scale" developed by Fabes, Eisenberg, and Bernzweig (1990) and adapted into Turkish by Yagmurlu and Altan (2010) has been used. The scale consists of 12 scenarios which include negative emotions of children such as anger, fear, sadness, anxiety, shame and frustration, and six reaction approaches in conformance with these scenarios are specified. Using these possible approaches, mothers are asked to state how much they will react to each scenario and indicate the frequency of that response. These six reactions form the sub-scales of the CCNES, and these are: problem-focused responses, emotion-focused reactions, encouraging reactions to emotion expression, insulting reactions, punitive reactions, and distress at parents. Each item in this scale is evaluated according to the five-point Likert type $(1=$ never do this, $5=$ definitely do the same). For collecting the scores of the question numbers in the six sub-scales, sub-scale scores are obtained and evaluated. In the study conducted by Altan-Aytun, Yagmurlu and Yavuz (2013), it was determined that the internal consistency coefficient of the scale was between .54 and .88, while the Cronbach alpha reliability coefficient in this study varies between .52 and .86 .

\section{Data Collection}

The data collection was carried out after obtaining the necessary permission from the relevant departments and the mothers of the 48-72-month-old children receiving education at the preschool institutions who agreed to participate in the study. Parents were sent forms that consisted of information about the aim of the study and scale, and also, they were told that their children's and their identities would remain anonymous, and that participation was based on voluntariness. The "Personal Information Form," "Short Temperament Scale for Children" and "Coping with Children's Negative Emotions Scale" were filled out and sent by the mothers. Data Analysis 
The data obtained from the research were analyzed using the SPSS 18.0 software package. Before the analysis, the research data were investigated regarding the premises of accuracy, missing values and meeting normalization. After excluding the missing values from the analysis, the arithmetic mean, standard deviation, skewness and kurtosis values of the scales were examined, and it was found that the scores showed normal distribution. The relationships between the variables were calculated using the Pearson correlation coefficient, and multiple and simple linear regression analyses.

\section{RESULTS}

\section{Descriptive Statistics}

The results of the descriptive statistics of the research data are presented in Table 1.

Table 1. Descriptive Statistics Related to Coping with Children's Negative Emotions Scale (CCNES) and Short Temperament Scale for Children

\begin{tabular}{lccccc}
\hline & $\begin{array}{c}\text { Arithmetic } \\
\text { Mean }\end{array}$ & Median & $\begin{array}{c}\text { Standard } \\
\text { Deviation }\end{array}$ & Skewness & Kurtosis \\
\hline CCNESShort & 219.54 & 220.50 & 24.76 & .099 & .321 \\
Temperament Scale & 112.71 & 113.00 & 13.31 & .068 & -.121 \\
& & & & & \\
\hline
\end{tabular}

The arithmetic deviation for the CCNES is calculated as 219.54 , the median is 220.50 , the standard deviation is 24.76 , skewness is .099, and kurtosis is .321. For the Short Temperament Scale for Children, the arithmetic deviation is 112.71 , the median is 113.0 , standard deviation 13.31, skewness is .068 and kurtosis is -.121. These findings reveal that the CCNES scores and Short Temperament Scale scores show a normal distribution.

Correlation Between the Variables

The results of the Pearson correlation coefficient, which determines the relationships between the variables, are given in Table 2 .

When Table 2 is examined, it is seen that there is no significant difference between CCNES scale total scores and Short Temperament Scale for Children scores $(r=.098 p<0.01)$. It is seen that the CCNES scale distress at parents sub-dimension and the Short Temperament Scale for Children reactivity sub-dimension have a significant relationship $(\mathrm{r}=.233 \mathrm{p}<0.01)$; when the CCNES scale punitive reactions sub-dimension and the Short Temperament Scale for Children reactivity sub-dimension are examined, it is determined that there is a low-level significant relationship ( $\mathrm{r}=.303 \mathrm{p}<0.01)$; when the CCNES scale insulting reactions sub-dimension and the Short Temperament Scale for Children reactivity sub-dimension are examined, it is seen that there is a positive low-level significant relationship ( $\mathrm{r}=.222 \mathrm{p}<0.01)$; the CCNES scale insulting reactions sub-dimension and the Short Temperament Scale for Children rhythmicity subdimension have a negative low-level significant relationship ( $\mathrm{r}=-.215 \mathrm{p}<0.01$ ); the CCNES scale encouraging reactions to emotion expression sub-dimension and the Short Temperament Scale for Children reactivity sub-dimension have a negative low-level significant relationship ( $\mathrm{r}=-.167$ $\mathrm{p}<0.01$ ); the CCNES scale encouraging reactions to emotion expression sub-dimension and the Short Temperament Scale for Children persistence sub-dimension have a positive low-level significant relationship $(\mathrm{r}=.188 \mathrm{p}<0.01)$. 
Table 2. Pearson Correlation Coefficient Results Showing the Relationship Between Scores for Coping with Children's Negative Emotions Scale and Short Temperament Scale for Children

\begin{tabular}{|c|c|c|c|c|c|c|c|c|c|c|c|c|}
\hline Variable & 1 & 2 & 3 & 4 & 5 & 6 & 7 & 8 & 9 & 10 & 11 & 12 \\
\hline $\begin{array}{l}\text { (1)CCNES Total } \\
\text { Score }\end{array}$ & 1.00 & ,599** &, $515^{* *}$ &, $683^{* *}$ &, $601^{* *}$ &, $553^{* *}$ &, $624^{* *}$ & ,098 & ,096 & 020 & 130 &,- 102 \\
\hline $\begin{array}{l}\text { (2)Distress at } \\
\text { Parents (CCNES) }\end{array}$ & & 1.00 &, $493^{* *}$ &, $489 * *$ & 143 & 125 & 114 & ,077 &, $233^{* *}$ &,- 023 &,- 012 &,- 105 \\
\hline $\begin{array}{l}\text { (3)Punitive } \\
\text { Reactions (CCNES) }\end{array}$ & & & 1.00 &, $633^{* *}$ &,- 115 &,$- 168 *$ &,- 112 &, 064 &, $303^{* *}$ &,- 137 &, 034 &,- 150 \\
\hline $\begin{array}{l}\text { (4)Insulting } \\
\text { Reactions (CCNES) }\end{array}$ & & & & 1.00 & ,039 & ,079 & 108 & ,014 &, $222^{* *}$ &,- 099 & ,037 &,$- 215^{* *}$ \\
\hline $\begin{array}{l}\text { (5)Encouraging } \\
\text { Reactions to } \\
\text { Emotion Expression } \\
\text { (CCNES) }\end{array}$ & & & & & 1.00 &, $451^{* *}$ & ,568** &, 074 &,$- 167 *$ & ,188* & ,078 & ,075 \\
\hline $\begin{array}{l}\text { (6)Emotion-focused } \\
\text { reactions (CCNES) }\end{array}$ & & & & & & 1.00 &, $713^{* *}$ & ,036 &,- 140 & ,056 & ,169* &,- 011 \\
\hline $\begin{array}{l}\text { (7)Problem-focused } \\
\text { reactions (CCNES) }\end{array}$ & & & & & & & 1.00 & ,090 &,- 099 & ,092 & ,156* & ,036 \\
\hline $\begin{array}{l}\text { (8)Short } \\
\text { Temperament Scale }\end{array}$ & & & & & & & & 1.00 &, $330 * *$ &, $628^{* *}$ &, $576^{* *}$ &, $419^{* *}$ \\
\hline Total Score & & & & & & & & & & & & \\
\hline (9)Reactivity & & & & & & & & & 1.00 &,- 138 &,- 117 &,$- 294^{* *}$ \\
\hline (10)Persistence & & & & & & & & & & 1.00 & 119 &, $291^{* *}$ \\
\hline (11)Friendliness & & & & & & & & & & & 1.00 & ,095 \\
\hline (12)Rhythmicity & & & & & & & & & & & & 1.00 \\
\hline
\end{tabular}

The Role of the Sub-Scales of the Coping with Children's Negative Emotions Scale in Predicting Temperament

Simple linear regression and multiple regression analyses were performed to determine the predictors of the temperament features of children variable. The results of the regression analysis are given in Table 3, Table 4 and Table 5.

When the results regarding the significance of the regression coefficient are examined, it is seen that only the CCNES Scale encouraging reactions to emotion expression sub-dimension is a significant predictor of the Short Temperament Scale reactivity sub-dimension. However, it is seen that punitive reactions, distress at parents and insulting reactions are not predictors. According to the standardized regression coefficient $(\boldsymbol{\beta})$, it is seen that the relative order of importance for the predictive variables of the Short Temperament Scale reactivity subdimension are encouraging reactions to emotion expression, punitive reactions, distress at parents, and insulting reactions, respectively. 
Table 3. Multiple Linear Regression Analysis for Determining the Effect of the CCNES SubDimensions on the Short Temperament Scale "Reactivity" Sub-Dimension

\begin{tabular}{lccccccc}
\hline Variable & B & $\begin{array}{c}\text { Standard } \\
\text { Error B }\end{array}$ & $\boldsymbol{\beta}$ & $\mathbf{T}$ & $\mathbf{p}$ & $\begin{array}{c}\text { Paired } \\
\mathbf{r}\end{array}$ & $\begin{array}{c}\text { Partial } \\
\mathbf{r}\end{array}$ \\
\hline Constant & 21.568 & 3.683 & - & 5.855 & .000 & - & - \\
$\begin{array}{l}\text { Distress at } \\
\text { Parents }\end{array}$ & .233 & .142 & .146 & 1.640 & .103 & -.233 & .127 \\
$\begin{array}{l}\text { Punitive } \\
\text { Reactions }\end{array}$ & .212 & .115 & .186 & 1.846 & .067 & .303 & .143 \\
$\begin{array}{l}\text { Insulting } \\
\text { Reactions }\end{array}$ & .041 & .102 & .040 & .404 & .687 & .222 & .032 \\
$\begin{array}{l}\text { Encouraging } \\
\text { Reactions } \\
\text { to Emotion } \\
\text { Expression }\end{array}$ & & & & & & & \\
\hline $\begin{array}{l}\mathrm{R}=.357 \\
\text { F=5.938 }\end{array}$ & -141 & .064 & -.167 & -2.203 & .029 & .167 & -.170 \\
\hline
\end{tabular}

Table 4. Simple Linear Regression Analysis for Determining the Effect of the CCNES "Insulting Reactions" Sub-Dimension on the Short Temperament Scale "Rhythmicity" Sub-Dimension

\begin{tabular}{lcccccc}
\hline Variable & $\mathbf{R}$ & $\mathbf{R 2}$ & $\begin{array}{c}\text { Standardized } \\
\boldsymbol{\beta}\end{array}$ & $\mathbf{t}$ & $\mathbf{F}$ & $\mathbf{p}$ \\
\hline Insulting Reactions & .215 & .046 & -.215 & -2.839 & 8.061 & .005 \\
\hline${ }^{\mathrm{p}} \mathrm{p}<0.01$ & & & & &
\end{tabular}

When Table 4 is examined, it is seen that the regression analysis results are significant at $(\mathrm{F}=8.061) \mathrm{p}<0.01$ level. When the results related to the significance of the regression coefficient are examined, it is determined that the CCNES Scale insulting reactions variable is a predictor of the Short Temperament Scale rhythmicity sub-dimension.

Table 5. Simple Linear Regression Analysis for Determining the Effect of the CCNES "Encouraging Reactions to Emotion Expression" Sub-Dimensions on the Short Temperament Scale "Persistence" Sub-Dimension

\begin{tabular}{lcccccc}
\hline Variable & $\mathbf{R}$ & $\mathbf{R 2}$ & $\begin{array}{c}\text { Standardized } \\
\boldsymbol{\beta}\end{array}$ & $\mathbf{t}$ & $\mathbf{F}$ & $\mathbf{p}$ \\
\hline $\begin{array}{l}\text { Encouraging Reactions } \\
\text { to Emotion Expression }\end{array}$ & .188 & .035 & .188 & -2.460 & 6.050 & .015 \\
\hline${ }^{*} \mathrm{p}<0.05$ & & & & &
\end{tabular}

When Table 5 is examined, it is seen that the regression analysis results are significant at $(\mathrm{F}=6.050) \mathrm{p}<0.05$ level. When the results related to the significance of the regression coefficient are examined, it is determined that the CCNES Scale encouraging reactions to emotion expression variable is a significant predictor of the Short Temperament Scale persistence sub-dimension.

\section{DISCUSSION and CONCLUSIONS}

When the results of the research are evaluated, it is seen that there is a relationship between the encouraging reactions to emotion expression sub-dimension, which is a supportive reaction of mothers towards negative emotions of children, and the persistence sub-dimension, one of the temperament features of children. In this case, it can be said that encouraging and supporting behaviors of mothers to encourage the child to express his/her emotions affects persistence, which is a situation in which the child concentrates on an activity positively, and that the mothers of children with persistence characteristics show more encouraging reactions. 
Preschoolers who have a fearful, negative or restless temperament but who experience a patient and supportive parenting are better at controlling their reactiveness, and it is possible to see a decrease in the difficulties they face (Berk, 2013). Kyrios and Prior (1991) state that persistence, which is one of the temperament characteristics of children, positively affects the emotions of children and is related to adaptation behaviors. Similarly, Blair, Denham, Kochanoff, and Whipple (2004) stated that parents' being explanatory and enthusiastic about meeting the needs of children about emotion is an important predictor of emotional competence and all social competences of preschool children. In addition to this, they revealed that the preschool children whose parents appear more negative have lower social competence than the ones whose parents tend to show more positive emotions when they are with their peers. Séguin and MacDonald (2018) state that temperament affects peer relations, self-management and emotion regulation. Aytar, Aksoy and Kaytez (2014) also found that there is a positively significant relationship between the personalities of mothers and children's' temperament.

As a result of the study, it was determined that there is an inverse relationship between the insulting reactions sub-dimension, one of the non-supportive reactions of mothers towards negative emotions of children, and the rhythmicity sub-dimension of children's temperament. It can be said that mothers' reactions that decrease the emotional reaction of the child and their not taking any notice of emotional reactions of children decrease the regularity of the child's needs (sleep, hunger, toilet, etc.) over time. Children with a difficult temperament face more negativity in their interactions with their mothers, and non-supportive expressions of the mother towards negative emotions negatively affect the temperament of children. It is probable that difficult children have not received sensitive care since infancy. When these children are two years old, their parents tend to be angry and use punitive discipline in a way that undermines the development of control that requires effort. As the child responds with objection and disobedience, parents become increasingly stressed. As a result, parents continue to use compulsive tactics, sometimes bowing to the child's disobedience, and discipline the child inconsistently by rewarding this behavior. These practices cause a continuity in restless and conflict-ridden behavior of the child, or even cause more (Berk, 2013). In a study on temperament, negative emotions and social relations variables, Fabes, Hanish, Martin and Eisenberg (2002) reported that the negative emotions of children who have strong temperament features may affect their social relations. In a study conducted by Walker, Berthelsen, and Irving (2001), it was detected that socially unaccepted children have strong temperament features when compared to popular children. Eisenberg, Cumberland and Spinrad (1998) found that the socialization practices of the mother and father affect the emotion and social competence of children, and also revealed that especially parents' negative emotions and negative reactions of children to emotion expression are connected with negative emotionality and low social competence of children. In the study by Ari and Yaban (2016), on determining the role of temperament features and emotion regulation skills on the social behaviors of children in the 4-6 years age group, it was determined that reactive children are less skillful in emotion regulation and display less positive social behavior. Similar studies supporting the idea that there is a relationship between negative emotions and temperament are also found in the literature (Guven, 2013; Korkmaz, 2016; Saritas \& Gencoz, 2011; Shewark \& Blandon, 2015; Silk et al., 2011).

When the results of the study are examined, it is seen that there is an inverse relationship between the reactions of mothers, which are supportive of the negative emotions of children, and the reactivity of children. It can be said that as the encouraging and assistive behaviors of mothers towards the child to express his/her emotion decrease, the child experiences a decrease in readiness to respond to a particular stimulus or event. The mothers of non-reactive children with an easy temperament have a positive effect on the temperament of children by using expressions and behaviors that support children's negative emotions, and also support them to find solutions to problems more easily. Pluess and Belsky (2010) state that compared to children with an easy temperament, children with a difficult temperament cause more trouble when they have low quality childcare, and when they have better quality childcare they cause less trouble. Rothbart and Bates (1998) state that the temperament of children can 
mediate the relationship between the reactions of parents and the adaptation of children (Cited by Kilic, 2012). Parents who give supportive reactions to children's emotions follow their children's emotions, see children's negative emotions as teaching opportunities, help them name their emotions, and follow a guiding approach to how they can cope with their emotions effectively. Children who take parents' behaviors as a model reflect these behaviors in their social relations by learning desired or undesired behaviors from them and motiving themselves in this direction (Santrock, 2014; Yavuzer, 2011). The family is a whole unit with mother, father, and children, and when the literature is reviewed, it is seen that there are studies explaining that not only mothers, but also fathers have an important role in emotion socialization and temperament (Baker, Fenning \& Crnic, 2011; Hastings \& De, 2008; Liliana \& Nicoleta, 2014).

As a result, temperament affects emotion socialization behaviors by determining the direction of interaction with the mother, and is also affected by these behaviors. Behaviors of parents in the development of children have an essential role in shaping every period of the lives of children, and their being healthy and happy individuals in the future. Children socialize with the verbal and non-verbal behavior of parents. Parents' behaviors toward their children significantly affect children's emotional socialization skills and temperament and have a longterm impact on their emotional development.

Parents can transform the environment of the child into an environment that is built on his/her strengths. The creation of environments that take into account the nature of each child facilitates the adaptation between the child's temperament and environmental demands that the child needs to cope with (Berk, 2013; Santrock, 2011). For this reason, it is important that a healthy relationship should be established in the family, and parents should be sensitive to their children. Moreover, they should show an attitude that shares and accepts the emotions and thoughts of their children.

Temperament has a biological basis, but it is a developing aspect of behavior. Selfperception, which completes the personality of a child, and behavioral preferences develop through experiences, and studies show that bringing up a child has an important role in changing the characteristics of biological-based temperament (Berk, 2013; Santrock, 2011). In this respect, it is thought that if parents become a model for children in expressing emotions, guide them about their feelings and encourage them to express their emotions, these will create a positive effect on the temperament of children. Based on the results of this study, the following suggestions can be made:

By knowing children's temperament traits, parents can develop appropriate responses, and training programs and workshops on temperament can be prepared for parents to make them the right model for their children and guide them; also, awareness about supportive reactions to children's negative feelings can be created in families.

These trainings can help parents to be positive and sensitive to the temperament and emotions of their children and encourage them to be the right model for their children by expressing their own negative emotions appropriately in the family and to encourage their children to express their negative feelings appropriately.

In this study, the data was obtained based on the opinions of mothers. Future studies can be conducted not only with mothers, but also with fathers.

Multiple data can be collected by using qualitative and quantitative methods together in further studies. Also, new data collection tools can be developed to collect data in this field. Interviews can be made with mothers and the behavior of children can be observed in the natural environment, and the data obtained can be supported. Similar studies can be conducted with different sample groups (refugee children, single-parent children, etc.).

\section{REFERENCES}

Altan-Aytun, Ö., Yağmurlu, B. \& Yavuz, H. M. (2013). Turkish mothers' coping with children's negative emotions: A brief report. Journal of Child and Family Studies, 22(3), 437-443.

Aytar, A.G. Aksoy, A. B. \& Kaytez, N. (2014). Anne kişiliği ve çocuğun mizaç özelliği [Mothers personality and feature temperament of their child]. Uşak Üniversitesi Sosyal Bilimler Dergisi, 7 (3), 237-251. 
Arı, M. \& Yaban, H. (2016). Okulöncesi dönemdeki çocukların sosyal davranışları: mizaç ve duygu düzenlemenin rolü [Social behavior in preschool children: the role of temperament and emotion regulation]. Hacettepe Üniversitesi Eğitim Fakültesi Dergisi, 31(1), 125-141.

Baker, J.K., Fenning, R. M. \& Crnic, K.A. (2011). Emotion socialization by mothers and fathers: coherence among behaviors and associations with parent attitudes and children's social competencesod. Social Development, 20 (2) 412-430. doi:10.1111/j.1467-9507.2010.00585.x

Bee, H. \& Boyd, D. (2009). Çocuk gelişim psikolojisi [Child developmental psychology]. O. Gündüz (Çev. Ed.). İstanbul: Kaknüs.

Berk, L.E. (2013). Bebekler ve çocuklar doğum öncesinden orta çocukluğa [Infants and children prenatal through middle childhood]. N. Işıkoğlu Erdoğan (Çev. Ed.). Ankara: Nobel.

Blair, K. A., Denham, S. A., Kochanoff, A., \& Whipple, B. (2004). Playing it cool: Temperament, emotion regulation, and social behavior in preschoolers. Journal of School Psychology, 42, 419-443.

Cassano, M., Perry-Parrish, C., \& Zeman, J. (2007). Influence of gender on parental socialization of children's sadness regulation. Social Development, 16, 210-231 https://doi.org/10.1111/j.14679507.2007.00381.x

Cole, P. M., Martin, S. E. \& Dennis, T. A. (2004). Emotion regulation as a scientific construct: Methodological challenges and directions for child development research. Child Development, 75 (2), $317-333$.

Denham, S.A., Mitchell-Copeland, J., Strandberg, K., Auerbach, S. \& Blair, K. (1997). Parental contributions to preschoolers' emotional competence: Direct and indirect effects. Motivation and Emotion, 21(1), 65-86.

Eisenberg, N., Cumberland, A. \& Spinrad, T. L. (1998). Parental socialization of emotion. Psychological Inquiry, 9 (4), 241-273.

Eisenberg, N., Spinrad, T. L. \& Cumberland, A. (1998). The socialization of emotion: Reply to commentaries. Psychological Inquiry, 9 (4), 317-333.

Fabes, R. A., Hanish, L. D., Martin, C. L., \& Eisenberg, N. (2002). Young children's negative emotionality and social isolation: A latent growth curve analysis. Merrill-Palmer Quarterly, 48 (3), 284-307.

Liliana, B. \& Nicoleta, T. M. (2014). Personality, family correlates and emotion regulation as wellbeing predictors. Procedia-Social and Behavioral Sciences, 159, 142-146.

Güven, E. (2013). Çocuğun davranış sorunları ile algıladığı anne baba çatışması arasındaki iliş̧kiler: Duygu sosyalleștirmenin aracı rolü [The relatıons between children's behaviour problems and interparental conflict appraisals: mediator role of emotion socialization]. (Yüksek Lisans Tezi). Ankara Üniversitesi \Sosyal Bilimler Enstitüsü, Ankara.

Hastings, P.D. \& De, I. (2008). Parasympathetic regulation and parental socialization of emotion: Biopsychosocial processes ofadjustment in preschoolers. Social Development, 17(2), 211-238. doi: 10.1111/j.1467-9507.2007.00422.x

Karasar, N. (2016). Bilimsel araştırma yöntemi [Scientific research method]. Ankara: Nobel Yayıncllık.

Kılıç, Ş. (2012). 48-72 aylık çocukların duyguları anlama becerisi ve annelerin duyguları sosyalleştirme davranışları arasindaki ilişki [The relationship between children's emotion understanding aged between 48-72 months of age and maternal emotional socialization behavior]. (Doktora Tezi). Gazi Üniversitesi \Ĕ̈itim Bilimleri Enstitüsü, Ankara.

Korkmaz, D. (2016). Longitudinal relations of maternal socialization and temperament with internalizing and externalizing behavior problems during middle childhood. (Yüksek Lisans Tezi). Özyeğin Üniversitesi \Sosyal Bilimler Enstitüsü, İstanbul.

Kyrios, M. \& Prior, M. (1991). Temperament, stress and family factors in behavioral A-adjustment of 3-5 year-old children. International Journal of Behavioral Development, 13, 67-93. https://doi.org/10.1177/016502549001300105.

Özen-Uyar, R., Yılmaz Genç, M. M. \& Aktaş Arnas Y. (2018). Emotion regulation and emotion understanding in preschoolers as a predictor of the maternal socialization of emotion. Education and Science, 43 (195), 1-17.

Pluess, M. \& Belsky, J. (2010). Children's differential susceptibility to effects of parenting. Family Science, $1(1), 14-25$.

Root, A. K. \& Denham, S. A. (2010). The role of gender in the socialization of emotion: Key concepts and critical issues. New Directions For Child and Adolescent Development, 128, 1-9. doi: 10.1002/cd.265.

Rothbart, M. K., \& Bates, J. E. (2007). Temperament in children's development. In W. Damon, R. Lerner, \& N. Eisenberg (Eds.), Handbook of child psychology: Social, emotional, and personality development (Vol. 3). New York: Wiley. (2) (PDF) Handbook of Child Psychology. Available from: https://www.researchgate.net/publication/229633680_Handbook_of_Child_Psychology [accessed Mar 25 2019]. 
Ruppert, F. (2014). Travma, bağlanma ve aile konstelasyonları ruhun yaralarını anlamak ve iyileștirmek [Trauma, attachment and family constellations]. F. Zengin (Çev). İstanbul: Kaknüs Yayınları.

Santrock, J. W. (2011). Yaşam boyu gelişim [Life-span development]. G. Yüksel (Çev.Edt). Ankara: Nobel Yayıncillk.

Sarıtaş, D. \& Gençöz, T. (2011). Ergenlerin duygu düzenleme güçlüklerinin, annelerinin duygu düzenleme güçlükleri ve çocuk yetiştirme davranışları ile ilişkisi [Adolescents' emotıon regulation and its relation with their mothers' emotion regulation and parental rearing behaviors]. Çocuk ve Gençlik Ruh Sağlığı Dergisi,18 (2), 117-126.

Seçer, Z. (2017). Sosyal olarak yetkin okul öncesi çocukların duygu düzenlemeleri ile annelerinin duygu sosyalleştirme davranışları arasındaki ilişkiler [The relations between emotional regulations of social competent preschool children and emotional socialization behaviours of their mothers]. Kastamonu Eğitim Dergisi, 25 (4), 1435-1452.

Séguin, D. G. \& MacDonald, B. (2018). The role of emotion regulation and temperament in the prediction of the quality of social relationships in early childhood. Early Child Development and Care, 188 (8), 1147-1163. Doi: 10.1080/03004430.2016.1251678

Shewark, E. A. \& Blandon, A. Y. (2015). Mothers' and fathers' emotion socialization and children's emotion regulation: A within-family model. Social Development, 24 (2), 266-284. doi: 10.1111/sode.12095

Silk, J. S., Shaw D.S., Prout, J.T., O'Rourke, F., Lane, T.J. \& Kovacs, M. (2011). Socialization of emotion and offspring internalizing symptoms in mothers with childhood-onset depression. Journal of Applied Developmental Psychology, 32 (3), 127-136.

Southam-Gerow, M.A. (2014). Çocuklarda ve ergenlerde duygusal düzenleme [Emotion regulation in children and adolescents]. M. Şahin (Çev.Edt). Ankara: Nobel.

Soysal, A. Ş. \& İșeri, E. (2010). Bebeklerde bağlanmanın gelişimi ve belirlenmesi/değerlendirilmesi. T. Solmuş (Editör:). Bağlanma, evlilik ve aile psikolojisi Türkiye bağlanma el kitabı [Attachment, marriage and family psychology]. İstanbul: Sitem Yayıncllık.

Thomas, A. \& Chess, S. (1977). Temperament and development. New York: Brunner/Mazel.

Trawick-Smith, J. (2014). Erken çocukluk döneminde gelişim (çok kültürlü bir bakış açısı) [Early childhood development a multicultural perspective]. B. Akman (Çev. Edt). Ankara: Nobel.

Walker, S., Berthelsen, A., \& Irving, K. (2001). Temperament and peer acceptance in early childhood: Sex and social status differences. Child Study Journal, 31 (3), 177-192.

Yağmurlu, B. \& Altan, O. (2010). Maternal socialization and child temperament as predictors of emotion regulation in Turkish preschoolers. Infant and Child Development, 19, 275-296.

Yağmurlu, B., \& Sanson, A. (2009). Acculturation and parenting among Turkish mothers in Australia. Journal of Cross-Cultural Psychology, 40 (3), 361-380.

Yavuzer, H. (2011). Ana-baba ve çocuk [Parents and children]. İstanbul: Remzi 